Accepted ver.

Ecological indicators. - ISSN 1470-160X. - Vol. 89 (Jun. 2018): 281-289

doi: 10.1016/j.ecolind.2018.02.001

\title{
Toward objective assessment of the conservation status of (the Natura 2000) forest habitat types: a comparison of a qualitative and a quantitative modeling approach
}

\author{
Marko Kovac ${ }^{\mathrm{a}^{*}}$, Petra Grošelj ${ }^{\mathrm{b}}$

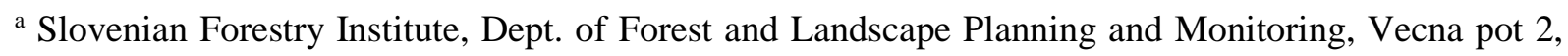 \\ 1000 Ljubljana, Slovenia; \\ ${ }^{\mathrm{b}}$ University of Ljubljana, Biotechnical Faculty, Jamnikarjeva 101, 1000 Ljubljana, Slovenia; \\ *marko.kovac@gozdis.si
}

\begin{abstract}
To halt the loss of biodiversity in natural habitats, the EU passed the Habitats Directive and established the Natura 2000 network. The network captured forest habitats and habitat types, whose conservation status must be reported under Article 17 of the Directive. Hence, the harmonization of habitat assessment methods and reporting formats are a critical issue. So far, the EU Commission and Member States have managed to design and issue reporting guidelines. However, as many of these reports are largely based on expert opinions, they tend to be biased and incomparable. To make conservation status assessments and reporting more consistent, this study evaluated a set of indicators with two decision support models. The DEX model operated with linguistic statements derived from numerical values, while the fuzzy model utilized numeric input. Both models were tested with data from Slovenia's three largest forest habitat types (FHT), namely 9110 - Luzulo-Fagetum beech forests, 91K0 - Illyrian Fagus sylvatica forests (Aremonio-Fagion) and 91L0 - Illyrian oak-hornbeam forests (Erythronio-Carpinion), provided by the Forest and Forest Ecosystem Condition Survey. The DEX model produced uniform results and defined the conservation status of all three FHTs as least favorable. Conversely, the fuzzy model produced three different conservation status grades for the FHTs: a favorable conservation status for the 91K0 FHT, least favorable for the 9110 FHT and unfavorable for the 91L0 FHT. Its results were logical and in accord with the existing assessments. The study showed that both models could be used for the evaluation of FHT traits. However, because of its larger sensitivity, the fuzzy model allowed detecting subtle differences among the indicator values due to the use of continuous numerical data and more sophisticated mathematical procedures.
\end{abstract}

Keywords: biodiversity, decision-making model, DEX, fuzzy logic, inference rules

Highlights

- The DEX model is easier to apply but produces less distinctive results.

- The fuzzy model is sensitive and detects differences among forest habitat types.

- Introduced indicators help define the conservation status of forest habitat types.

- Sets of common forest habitat conservation status indicators need to be defined.

- Rule based assessments make the reports of forest habitat types less biased.

\section{Introduction}

The notion of conservation status of natural habitats was introduced into the European concept of nature conservation by the Habitats Directive (Directive; OJEC, 1992). The Directive defines the conservation status as "the sum of the influences acting on a natural habitat and its typical species that may affect its long-term natural distribution, structure and functions, as well as the long-term survival of its typical species within the territory" (OJEC, 1992). The Directive also defines the conservation status of a natural habitat as favorable if i) the natural range and areas it covers within that range are stable or increasing, ii) its specific structure and functions that are necessary for its long-term maintenance exist and are likely to continue to exist for the foreseeable future and iii) the conservation status of its typical species is also favorable. As the Directive does 
not specifically address any land cover entity, the notion of natural habitats refers to forest habitat types (FHTs), their subtypes (Kovač et al., 2016) and the habitats of their typical plant and animal species, whenever dealing with the Natura 2000 forestlands.

The concept of conservation status has been criticized for some time due to its many deficiencies. While the recently proposed sets of indicators and assessment methods (Cantarello and Newton, 2008; Kovač et al., 2016), which still need to be fulfilled and tested, certainly represent a step toward greater objectivity, the vaguely defined conditions of the favorable conservation status of FHTs continue to be questioned (Mehtälä and Vuorisalo, 2007).

Developing habitat conservation status assessment methods has progressed slowly as well. Their main objective is to evaluate available data and express them in the form of three conditions of the conservation status (first paragraph; i, ii, iii) with simple numerical values (e.g. 1, 2, 3) or with statements such as "favorable", "least favorable" and "unfavorable". Until recently, only decision support models based on simple calculations, linear sums and weighted summations have been presented (Hernando et al., 2010; Šmelko and Fabrika, 2007; Velázquez et al., 2010). All use diverse criteria (syn. indicators) whose data are obtained in many ways such as expert opinion, field inventorying, mapping and remote sensing.

A certain number of evaluation methods also have been developed by national agencies (Ellmauer and Essl, 2005; Müller-Kroehling et al., 2004). Pursuant to recommendations (Evans and Arvela, 2011; Salafsky et al., 2008), these methods commonly require data about FHTs' areas, ranges, structures and prospects for long term survival. However, because their indicators are defined ambiguously, as well as the data are often based on expert opinion, these methods generally produce biased and incomparable results at all spatial scales (i.e. sites, biogeographic domains and nations).

Many more evaluation models are developed for the needs of different environmental sectors. They are based on multiple-criteria decision making and artificial intelligence techniques such as neural networks, machine learning, and fuzzy sets. A well-recognized and widely used model type is multiple-criteria decision analysis (MCDA) (Zopounidis and Doumpos, 2002). Its models are commonly used to address multiple and possibly conflicting quantitative and qualitative criteria. The main approaches are multi-attribute utility theory (MAUT), outranking methods (PROMETHEE, ELECTREE) and analytic hierarchy process (AHP) (Ananda and Herath, 2009; Diaz-Balteiro and Romero, 2008; Herva and Roca, 2013; Huang et al., 2011; Kangas and Kangas, 2005).

Uncertainty, imprecision, vagueness and subjectivity of indicators are common in environmental studies. Usually they are expressed by linguistic terms and/or by fuzzy numbers, originating in the concept of fuzzy sets (Zadeh, 1965). Analysts have integrated uncertainty into i) qualitative multi-attribute models (Bohanec et al., 2012), to assess the impacts of urbanization on natural habitats (Scolozzi and Geneletti, 2012) and mountain lodge management in the Alps (Stubelj Ars and Bohanec, 2010), ii) fuzzy analytic hierarchy process (AHP) for urban land-use planning (Mosadeghi et al., 2015), iii) forest fire risk modelling (Kant Sharma et al., 2012) and iv) environmental impact assessment studies (Kaya and Kahraman, 2011).

A special fuzzy model family represent fuzzy inference systems (FIS) which combine fuzzy logic with inference rules. These models have evolved from artificial intelligence and knowledge-based systems and can process non-linear information that reflects human experiences, knowledge and thoughts (Gharibi et al., 2012). Similar to the earlier introduced models, these also produce outcomes in the form of numeric ranges (an arbitrary numeric range or the range between 0 and 1) that can be transformed into linguistic variables which are understood by non-specialists (Silvert, 2000). Such models are currently being used to evaluate environmental properties and quality (Peche and Rodríguez, 2012), water quality and management (CarbajalHernández et al., 2012b; Che Osmi et al., 2016; Gharibi et al., 2012; Lermontov et al., 2009; Mahapatra et al., 2011; Ocampo-Duque et al., 2006; Yan et al., 2010), forest conditions (Ochoa-Gaona et al., 2010), habitat quality (Mocq et al., 2013), decision support in ecosystem management (Adriaenssens et al., 2004) and exploration of population ecology (Kampichler et al., 2000).

Despite their contribution to better decision making, the models differ significantly. Models, such as DEX, combining the features of qualitative multiple-criteria and rule-based expert systems (Bohanec and Rajkovic, 1990), commonly operate solely with linguistic statements defined by experts. Because of this simplicity they 
may produce less precise results, yet, they are more easily evaluated and understood by end-users. Conversely, FIS models, integrating multi-criteria decision models and fuzzy sets, are likely more accurate due to the concrete (measured) data input and expert judgments, but are more demanding in view of mathematical knowledge and general understanding.

In this study, we compared the adequacy of the DEX and fuzzy models for assessing the conservation status of FHTs and subtypes. With the comparison, we aimed to show that the fuzzy model is more sensitive in detecting differences between FHT status. Additionally, we juxtaposed both models with the models currently in use. Finally, we discussed the state of the art in the Natura 2000 forest habitat type reporting in the view of international processes and argued for greater objectivity.

\section{Methods and material}

\subsection{Criteria, data and methods}

Models and criteria (syn. indicators) were tested with data of Slovenia's three largest FHTs, namely 9110 Luzulo-Fagetum beech forests, 91K0 - Illyrian Fagus sylvatica forests (Aremonio-Fagion) and 91L0 - Illyrian oak-hornbeam forests (Erythronio-Carpinion) (Kutnar et al., 2011). These FHTs, native to many countries across Europe (European Commission, 2007), represent 22.6 \%, $48.0 \%$ and $7.2 \%$ of national forestlands, respectively. All three FHTs are subject to reporting.

Apart from the Forest patch area indicator (ForA; Table 1), the remaining habitat evaluation indicators were taken from the study of Kovač et al. (2016). We used 10 of 18 indicators from the spatial, structural and viability groups (Table 1). The ForA indicator was computed solely for this study. Its computation was performed in the same manner as for the Patch size indicator (PSFHT; Table 1). The indicators were selected subjectively. Regardless, we accounted for representativeness of all three components of the conservation status, likely correlations (e.g. weighted mean patch size, median patch size; see Kovač et al. 2016) and the relevancy of the indicators for biodiversity (e.g. total area, type of regeneration; Kovač et al. 2016).

The 2012 Forest and Forest Ecosystem Condition Survey database (GIS/SFI, 2013) was used for computing the indicator estimates such as means, variances and percentiles. The data set consisted of 614 sample units; 166 of them belonged to the 9110 - Luzulo-Fagetum beech forests, 392 to the 91K0 - Illyrian Fagus sylvatica forests, and 56 sample units to the 91L0 - Illyrian oak-hornbeam forests. All the estimates were derived by conventional formulas. The Statistica v. 10.0 statistical package was used for computations (StatSoft-Inc, 2011).

Table 1: Indicators used for conservation status model construction (FHT = forest habitat type; DW = deadwood; dbh=diameter at breast height; ID = The number of the indicator in the study of Kovač et al. (2016).

\begin{tabular}{|l|l|l|c|c|}
\hline $\begin{array}{l}\text { Criteria } \\
\text { group }\end{array}$ & Name & Meaning (definition) & Unit & ID \\
\hline Spatial & Core & Mean core (i.e. forest belt) diameter & $\mathrm{m}$ & 2 \\
\hline Spatial & ForA & Mean forest patch size within a sample frame of $1 \mathrm{~km}^{2}$ & ha & - \\
\hline Spatial & NofFHT & $\begin{array}{l}\text { Number of different FHTs within a sample frame of } 1 \mathrm{~km}^{2} \\
\text { (density) }\end{array}$ & - & 6 \\
\hline Spatial & PSFHT & Mean FHT patch size within a sample frame of $1 \mathrm{~km}^{2}$ & ha & 7 \\
\hline Structural & $\begin{array}{l}\text { Species } \\
\text { composition }\end{array}$ & $\begin{array}{l}\text { Share (\%) of dominant species (spruce, beech, fir and sessile } \\
\text { oak, hornbeam) }\end{array}$ & $\%$ & 8 \\
\hline Structural & $\begin{array}{l}\text { Development } \\
\text { phase }\end{array}$ & $\begin{array}{l}\text { Share (\%) of young growth and pole stand combined; dbh }<30 \\
\text { cm }\end{array}$ & $\%$ & 9 \\
\hline Structural & Vol & Standing volume of timber wood (sawlogs; dbh $\left.>29.99 \mathrm{~cm}^{2}\right)$ & $\mathrm{m}^{3} \mathrm{ha}^{-1}$ & $11 \mathrm{a}$ \\
\hline Structural & Dwtotal & Amount of total deadwood volume & $\mathrm{m}^{3} \mathrm{ha}^{-1}$ & 12 \\
\hline Structural & DW $\geq 30$ & Amount of standing and downed coarse woody debris & $\mathrm{m}^{3} \mathrm{ha}^{-1}$ & $12 \mathrm{a}+12 \mathrm{~b}$ \\
\hline Viability & Recruitment & $\begin{array}{l}\text { Share of dominant and co-dominant tree species with dbh }<10 \\
\text { cm }\end{array}$ & $\%$ & 14 \\
\hline Viability & Damaged & Share of (more than 25\% defoliated) trees & $\%$ & 15 \\
\hline
\end{tabular}

\subsection{DEX model theory}


DEX (Bohanec and Rajkovic, 1990) is a qualitative decision support system whose criteria are evaluated via linguistic terms such as "favorable", "least favorable" and "unfavorable". The model is generally constructed in three stages (Rozman et al., 2009): i) identifying and establishing the hierarchical structure of input criteria; ii) defining the linguistically ordered value scale for each criterion, and; iii) defining the decision rules.

The first stage required developing a hierarchical decision tree of all introduced groups of criteria and individual criteria. In the second stage, discretely ordered linguistic scales were defined for each group of criteria and each criterion. Finally, in the third stage, IF-THEN decision rules were set. These rules represent the utility functions for aggregated criteria. The general form of a decision rule is:

\section{IF $P$ is $p$, THEN $Q$ is $q$,}

whereby $p$ and $q$ are the linguistic terms of linguistic variables $P$ and $Q$, respectively.

The logical operator AND is applied in the IF part, if the decision rule consists of $n$ parts:

IF $\left(P_{1}\right.$ is $p_{1}$ AND $P_{2}$ is $p_{2}$ AND ... AND $P_{n}$ is $\left.p_{n}\right)$, THEN $Q$ is $q$,

whereby $p_{1}, p_{2}, \ldots, p_{n}$ are the linguistic terms for linguistic variables $P_{1}, P_{2}, \ldots, P_{n}$, respectively.

The input values were brought to the model through the leaves of a decision tree. They were aggregated through the hierarchy of the decision tree until the final output of the root node. The software program DEXi (Bohanec, 2013) was used for computations.

\subsection{Fuzzy logic model theory}

Fuzzy logic is an extension of Zadeh's (1965) classical fuzzy set theory. The membership functions of these sets denote the degree of membership of an object to the defined class. As element $x$ can only partly belong to fuzzy set $A$, fuzzy logic can also deal with imprecise information. The grade of membership of $x$ in $A$ is determined by the value of a membership function $\mu_{A}(x)$, ranging from 0 to 1 . Our model was constructed with the linear membership functions of triangular and trapezoidal shape because of their good performance and easy use (Carbajal-Hernández et al., 2012b).

The construction of the fuzzy logic model was executed in four stages. In the first, a hierarchical tree of quantitative criteria was developed. In the next two stages the fuzzy logic inference system (CarbajalHernández et al., 2012b; Jamshidi et al., 2013; Ocampo-Duque et al., 2006; Ross, 2004) was shaped. The Mamdani-type inference system (Mamdani and Assilian, 1975) was used due to its intuitive rules and better suitability to human-like nature (Che Osmi et al., 2016; Kovac et al., 2012). Accordingly, we first defined the membership functions of all criteria. Afterwards, in the fuzzification process, the data were transformed into the linguistic variables of fuzzy sets. The membership functions were used to associate the grades with the adequate linguistic terms.

In the third stage, IF-THEN decision rules were set. The basic fuzzy operations, used in the antecedent (IF part) and the consequent (THEN part) parts of rules, were:

intersection (AND)

$$
\mu_{A \cap B}(x)=\mu_{A}(x) \cap \mu_{B}(x)=\min \left(\mu_{A}(x), \mu_{B}(x)\right)
$$

union (OR)

$$
\mu_{A \cup B}(x)=\mu_{A}(x) \cup \mu_{B}(x)=\max \left(\mu_{A}(x), \mu_{B}(x)\right)
$$

and negation (NOT) (Ross, 2004)

$$
\mu_{\bar{A}}(x)=1-\mu_{A}(x)
$$

Criteria were aggregated by the max-min composition of membership functions 


$$
\mu_{C}(\mathrm{z})=\max \left(\min \left(\mu_{A}(x), \mu_{B}(\mathrm{y})\right)\right)
$$

whereby $\mu_{C}, \mu_{A}, \mu_{B}$ are the membership functions of output $z$ and inputs $x$ and $y$, respectively.

This composition is one of the most commonly used in the Mamdani inference model (Jamshidi et al., 2013; Monjezi and Rezaei, 2011; Ross, 2004).

The last, fourth stage involved the defuzzification process that transformed the aggregated fuzzy sets to crisp values. Among several possibilities (Gharibi et al., 2012; Ross, 2004) the Centre of gravity method was selected (Afrinaldi and Zhang, 2014; Carbajal-Hernández et al., 2012b; Jamshidi et al., 2013; Ocampo-Duque et al., 2006; Ross, 2004; Vesely et al., 2016)

$$
X^{*}=\frac{\int \mu(x) x d x}{\int \mu(x) d x},
$$

whereby $x^{*}$ is the defuzzified crisp value for the output variable $x$, and $\mu(x)$ is the aggregated output membership function. The value derived by the centroid function was normalized (Afrinaldi and Zhang, 2014; Carbajal-Hernández et al., 2012a) by the equation (8) so as to get the final result in the interval $[0,100]$.

$$
I=100 \cdot \frac{x^{*}-\min (x)}{\max (x)-\min (x)}
$$

All computations of the fuzzy logic model were performed in Excel v. 2010.

\subsection{Construction of the conservation status models}

\subsubsection{General}

We developed a qualitative DEX model and a quantitative fuzzy logic model. Both models shared the same hierarchical decision tree and IF-THEN decision rules.

\subsubsection{DEX Model}

In the first stage, we developed a hierarchical decision tree, composed of spatial, structural and viability indicator groups (Figure 1). The groups of criteria/indicators and individual criteria were given different weights, based on expert opinion. As shown in Figure 1, the larger the rectangle, the larger the amount of influence of the superior group of indicators or indicator. 


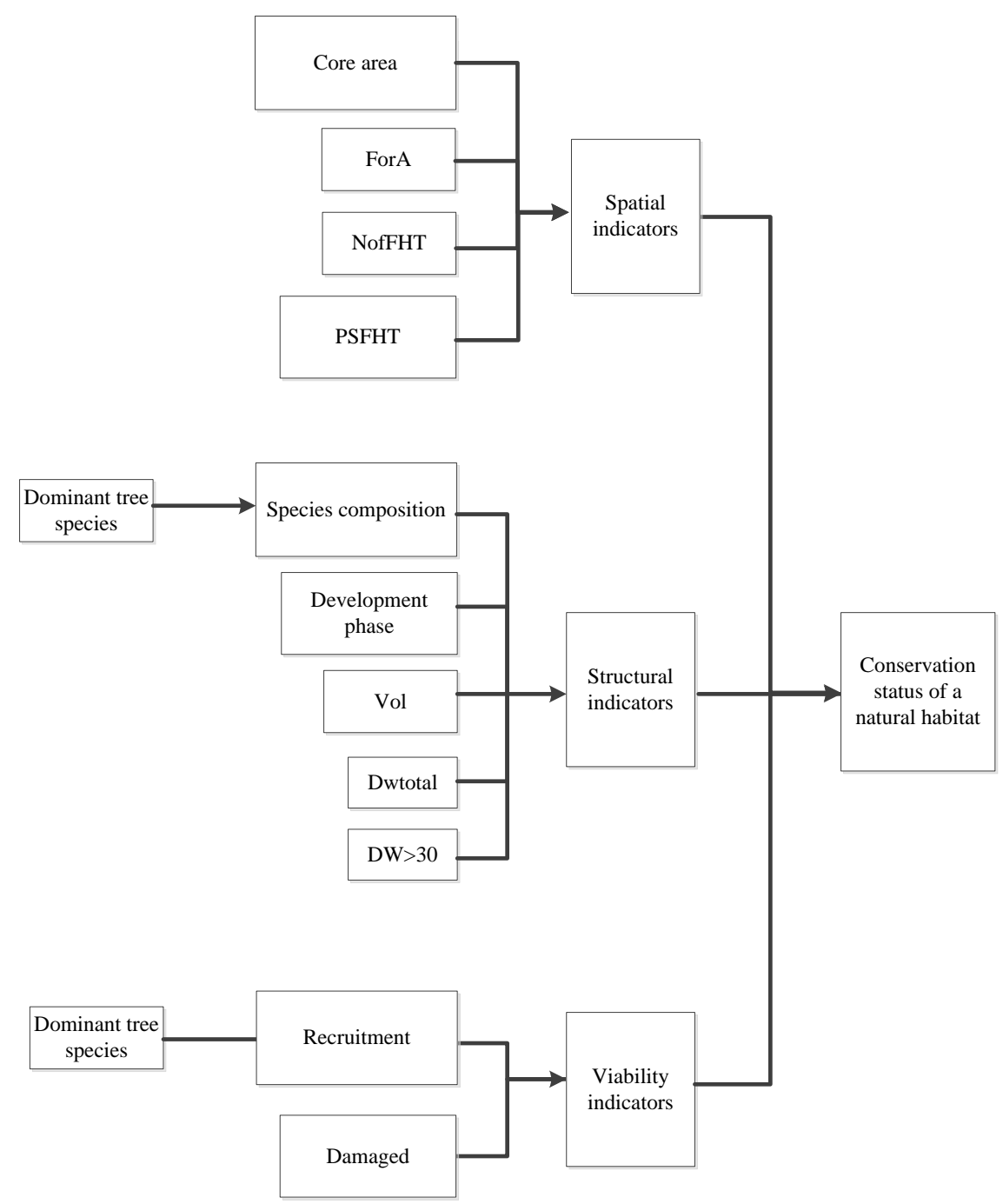

Figure 1: Hierarchical decision tree of the model for the conservation status of FHTs.

In the second stage, we defined an array of linguistic values and assigned them to the indicators. The unfavorable and favorable states were assigned to the criteria of Selected tree species (Species composition and Recruitment) and Development phase. In contrast, the unfavorable, least favorable and favorable states were assigned to all other groups of criteria, all remaining criteria, and to the Conservation status.

Finally, the values of quantitative criteria of selected FHTs were analyzed and ranked by expert judgment to correspond to the meaning of the linguistic values (Table 2). 
Table 2: Values of criteria, corresponding to the linguistic values

\begin{tabular}{|c|c|c|c|c|c|c|c|c|c|c|}
\hline \multirow[b]{2}{*}{ Criterion/Indicator } & \multirow{2}{*}{\begin{tabular}{|c|} 
FHT-> \\
unit \\
\end{tabular}} & \multicolumn{3}{|c|}{9110} & \multicolumn{3}{|c|}{$91 \mathrm{~K} 0$} & \multicolumn{3}{|c|}{ 91L0 } \\
\hline & & unfavorable & least favorable & favorable & unfavorable & least favorable & favorable & unfavorable & least favorable & favorable \\
\hline Core & $\mathrm{m}$ & $0-49$ & 50-199 & $200-350$ & $0-49$ & 50-199 & $200-350$ & $0-49$ & 50-199 & $200-350$ \\
\hline ForA & ha $\mathrm{km}^{-2}$ & $0-63$ & $64-96$ & $97-100$ & $0-63$ & $64-96$ & $97-100$ & $0-63$ & $64-96$ & $97-100$ \\
\hline NofFHT & $\# \mathrm{~km}^{-2}$ & $2.00-5.00$ & $1.00-1.99$ & $0-0.99$ & $2.00-5.00$ & $1.00-1.99$ & $0-0.99$ & $2.00-5.00$ & $1.00-1.99$ & $0-0.99$ \\
\hline PSFHT & ha $\mathrm{km}^{-2}$ & $0-39$ & $40-88$ & $89-100$ & $0-39$ & $40-88$ & 89-100 & $0-39$ & $40-88$ & $89-100$ \\
\hline Development phase & $\%$ & $0-44,56-100$ & - & $45-55$ & $0-44,56-100$ & - & $45-55$ & $0-44,56-100$ & - & $45-55$ \\
\hline Vol & $\mathrm{m}^{3} \mathrm{ha}^{-1}$ & $0-216$ & 217-639 & $640-950$ & 0-189 & $190-590$ & $591-1188$ & $0-141$ & $142-430$ & $431-568$ \\
\hline Dwtotal & $\mathrm{m}^{3} \mathrm{ha}^{-1}$ & $0-3.3$ & $3.4-23.8$ & $23.9-169$ & $0-3.3$ & $3.4-30.0$ & $30.1-250.2$ & $0-2.0$ & $2.1-18.6$ & $18.7-57.5$ \\
\hline $\mathrm{DW}>30$ & $\mathrm{~m}^{3} \mathrm{ha}^{-1}$ & $0-1.0$ & $1.1-15.6$ & $15.7-107.3$ & $0-1.0$ & $1.1-27.7$ & $27.8-94.1$ & $0-1.0$ & $1.1-12.5$ & $12.6-19.7$ \\
\hline \multirow[t]{2}{*}{ Damaged } & $\%$ & $51-100$ & $22-50$ & $0-21$ & $57-100$ & \begin{tabular}{|c|}
$19-56$ \\
\end{tabular} & $0-18$ & $60-100$ & $22-59$ & $0-21$ \\
\hline & \multicolumn{10}{|c|}{ Species composition, Recruitment } \\
\hline Norway spruce & $\%$ & & & & $31-100$ & - & $0-30$ & & & \\
\hline Common beech & $\%$ & $0-24$ & - & $25-100$ & $0-29$ & - & $30-100$ & $21-100$ & - & $0-20$ \\
\hline Silver fir & $\%$ & $31-100$ & - & $0-30$ & $71-100$ & - & $0-70$ & & & \\
\hline Sessile oak & $\%$ & $76-100$ & - & $0-75$ & $31-100$ & - & $0-30$ & $0-24,86-100$ & - & $25-85$ \\
\hline Hornbeam & $\%$ & & & & & & & $0-14,46-100$ & - & $15-45$ \\
\hline
\end{tabular}

Rem.; See Table 1 for variable names. 
In the third stage, the utility functions in the form of IF-THEN decision rules were defined.

i) At the aggregation of spatial indicators, Core was considered the most important and Mean patch size of FHT (PSFHT) the second most important indicator. Both Forest area within a sample frame (ForA) and Number of FHT within the frame (NofFHT) were considered equally important.

ii) All three characteristic tree species of each FHT were considered equally important for aggregating single tree species into Species composition and Recruitment.

For aggregating Structural indicators, Species composition was defined as the most important indicator, Development phase as the second most important and Volume (Vol) as the third most important indicator. Both Total deadwood (DWtotal) and Coarse deadwood (DW $>30$ ) were defined as less important indicators, because their desired conditions easily can be achieved in many ways (moving deadwood, girdling or felling a tree).

iii) Recruitment was defined as a more important indicator than Damaged for aggregating Viability indicators. iv) While aggregating the groups of indicators, the groups of spatial, structural-functional and viability indicators were defined as equally important.

The amount of criteria influence is shown in Figure 1. In addition, Table 3 denotes the IF-THEN decision rules for the Viability group of indicators.

Table 3: IF-THEN decision rules for Viability indicators

\begin{tabular}{|c|c|c|}
\hline IF Damaged is & AND Recruitment is & THEN Viability indicators are \\
\hline unfavorable & unfavorable & unfavorable \\
\hline unfavorable & least favorable & least favorable \\
\hline unfavorable & favorable & least favorable \\
\hline least favorable & unfavorable & unfavorable \\
\hline least favorable & least favorable & least favorable \\
\hline least favorable & favorable & favorable \\
\hline favorable & unfavorable & least favorable \\
\hline favorable & least favorable & least favorable \\
\hline favorable & favorable & favorable \\
\hline
\end{tabular}

\subsubsection{Fuzzy logic model}

The first stage of the fuzzy logic model was the same as of the DEX model (Figure 1). In the second stage, we constructed membership functions with the same criteria as for the DEX model. We developed the following five types of functions:

Type 1, (Figure 2-1) This Membership function was designed for the indicators of Core, ForA, PSFHT, Vol, DWtotal, DW $>30$, Species composition and Recruitment and for the groups of indicators, namely Spatial indicators, Structural indicators and Viability indicators. All denote three possible states, whereby higher values are favorable.

i) For the spatial indicators of Core, ForA and PSFHT, the parameters $a$ and $b$ were computed from all sample units $(n=614)$. This approach was used because all three FHTs are similarly affected by external environmental disturbances. Consequently, the two parameters of all FHTs share the same values as follows: $a=$ first quartile $(\mathrm{Q}(0.25)) ; b=$ third quartile $(\mathrm{Q}(0.75))$.

For the remaining indicators, the values of $a$ and $b$ were computed for each FHT separately:

ii) DWtotal: $a=\mathrm{Q}(0.25) ; b=\mathrm{Q}(0.75)$;

iii) Vol and DW > 30: $a=0.10$ percentile $(\mathrm{P}(0.10)) ; b=0.90$ percentile $(\mathrm{P}(0.90))$;

iv) aggregated indicators of Species composition and Recruitment and the groups of indicators i.e. Spatial indicators, Structural-functional indicators and Viability indicators: $a=25 ; b=75$.

Type 2, Figure 2-2) Membership function type 2 was constructed for defining the indicators of NofFHT and Damaged. This function has three possible states, with low values being favorable. 
i) As NofFHT is a spatial indicator, the values $a$ and $b$ were computed from all sample units (see Type 1, Figure 2, i) as follows: $a=\mathrm{Q}(0.25) ; b=\mathrm{Q}(0.75)$;

ii) For Damaged, both parameters were computed for each FHT separately, as follows: $a=\mathrm{Q}(0.25) ; b=$ $\mathrm{Q}(0.75)$.

Type 3, (Figure 2-3) This membership function was created for the indicators of Development phase, Hornbeam and Sessile oak (of Species composition and Recruitment) of the 91L0 FHT. The membership function is characterized by two possible states, with the favorable values in the middle; low and high values are unfavorable.

i) For the Development phase, we defined the favorable proportion of young trees between $45 \%$ and $55 \%$, which represents the interval $[b, c]$. Thus: $a=b-15 \% ; d=c+15 \%$;

ii) For Species composition and Recruitment we set the favorable proportion for Hornbeam between $15 \%$ and $45 \%$ and for Sessile oak between $25 \%$ and $85 \%$, which represented the interval [b,c]. Thus: $a=b-5 \%$ and $d=c+5 \%$.

Type 4, (Figure 2-4) Membership function type 4 was created for common beech (of Species composition) and Recruitment, whereby higher percentages of the tree species were favorable. The values refer to the 9110 and 91K0 FHTs. We used the same tree species ranges for the interval of $[b, \max ]$ as presented in Table 2 of the Kovač et al. (2016). That is:

i) For common beech (FHT 9110): $b=25 \%, a=b-5 \%$, $\min =0 \%$, $\max =100 \%$;

ii) For common beech (FHT 91K0): $b=30 \%, a=b-5 \%$, $\min =0 \%$, $\max =100 \%$.

Type 5, Figure 2-5) Membership function type 5 was constructed for the indicators of Silver fir (FHT 9110 and 91K0), Sessile oak (FHT 9110), Norway spruce (FHT 91K0), and common beech (FHT 91L0) of Species composition and Recruitment. In all cases the lower percentages of tree species were favorable. As before, the tree species ranges for the interval of [min, $a$ ] were set in accordance with Table 2 of the Kovač et al. (2016). That is: $b=a+5 \%$, $\max =100 \%$.

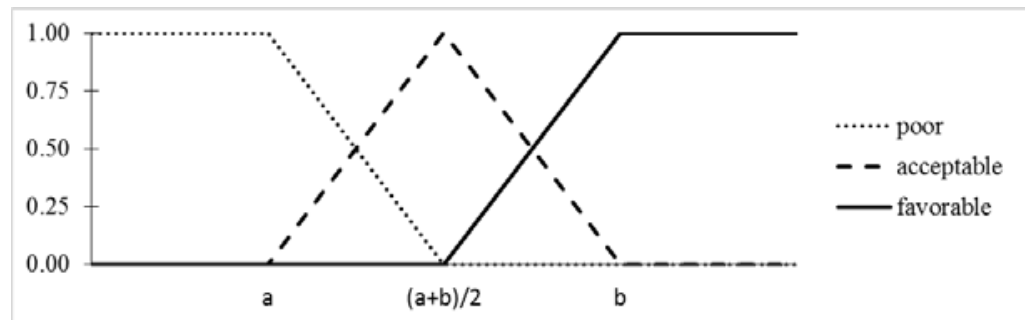

Figure 2-1: Membership functions of type 1

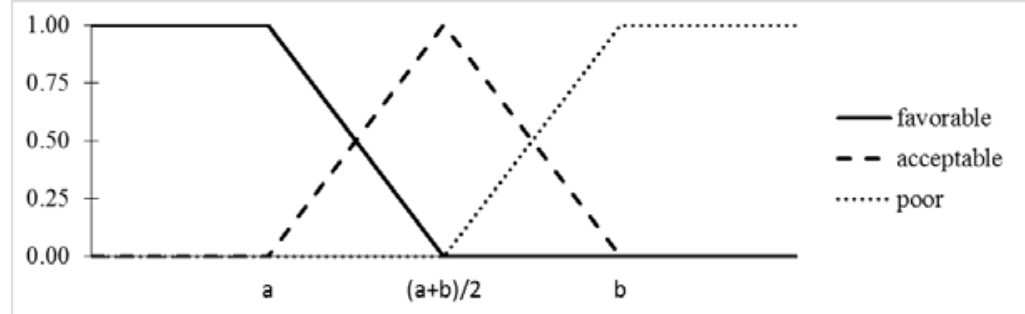

Figure 2-2: Membership functions of type 2

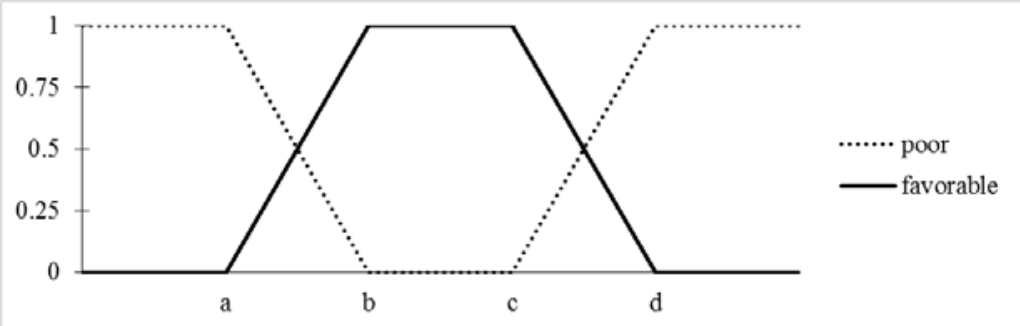

Figure 2-3: Membership functions of type 3 


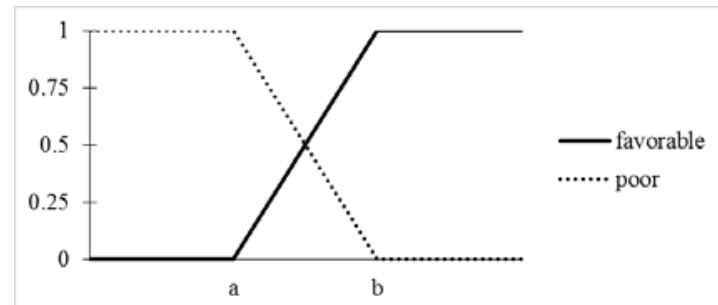

Figure 2-4 : Membership functions of type 4

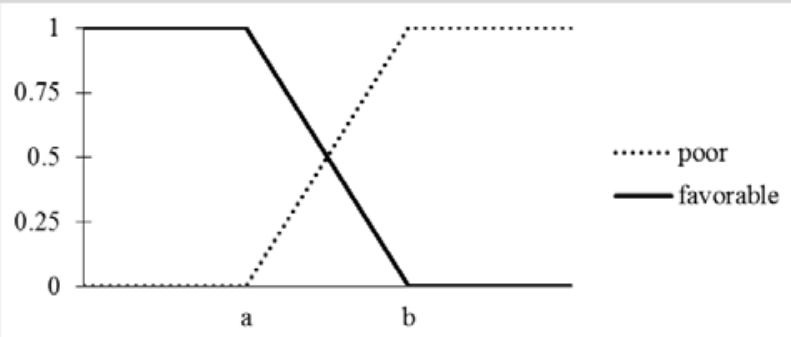

Figure 2-5: Membership functions of type 5 (for sub-indicators)

Table 4 presents the parameters for the membership functions with two parameters. Similarly, Table 5 summarizes the parameters for the membership functions with four parameters. 
Table 4: Parameters of membership functions (MF) of types 1, 2, 4 and 5 with two parameters $a$ and $b$

\begin{tabular}{|c|c|c|c|c|c|c|c|c|c|c|c|c|c|c|}
\hline \multirow[b]{2}{*}{ Criterion } & \multirow[b]{2}{*}{ Unit } & \multirow[b]{2}{*}{ MF Туре } & \multicolumn{4}{|c|}{ FHT 9110} & \multicolumn{4}{|c|}{ FHT 91K0 } & \multicolumn{4}{|c|}{ FHT 91L0 } \\
\hline & & & $\min$ & $\mathrm{a}$ & $\mathrm{b}$ & $\max$ & $\min$ & $\mathrm{a}$ & $\mathrm{b}$ & $\max$ & $\min$ & $\mathrm{a}$ & $\mathrm{b}$ & $\max$ \\
\hline Core & $\mathrm{m}$ & 1 & 0 & 50 & 200 & 350 & 0 & 50 & 200 & 350 & 0 & 50 & 200 & 350 \\
\hline ForA & ha $\mathrm{km}^{-2}$ & 1 & 9.08 & 64.30 & 97.31 & 100 & 9.08 & 64.30 & 97.31 & 100 & 9.08 & 64.30 & 97.31 & 100 \\
\hline NofFHT & $\# \mathrm{~km}^{-2}$ & 2 & 0 & 1 & 2 & 5 & 0 & 1 & 2 & 5 & 0 & 1 & 2 & 5 \\
\hline PSFHT & ha $\mathrm{km}^{-2}$ & 1 & 0.11 & 39.09 & 87.51 & 100 & 0.11 & 39.09 & 87.51 & 100 & 0.11 & 39.09 & 87.51 & 100 \\
\hline Species composition & $\%$ & 1 & 0 & 25 & 75 & 100 & 0 & 25 & 75 & 100 & 0 & 25 & 75 & 100 \\
\hline Norway spruce & $\%$ & 5 & & & & & 0 & 30 & 35 & 100 & & & & \\
\hline Common beech & $\%$ & $4,4,5$ & 0 & 20 & 25 & 100 & 0 & 25 & 30 & 100 & 0 & 20 & 25 & 100 \\
\hline Silver fir & $\%$ & 5 & 0 & 30 & 35 & 100 & 0 & 70 & 75 & 100 & & & & \\
\hline Sessile oak & $\%$ & 5 & 0 & 75 & 80 & 100 & & & & & & & & \\
\hline Vol & $\mathrm{m}^{3} \mathrm{ha}^{-1}$ & 1 & 36.87 & 216.77 & 639.99 & 950.01 & 0 & 189.11 & 590.91 & 1188.50 & 59.38 & 141.25 & 431.12 & 568.48 \\
\hline Dwtotal & $\mathrm{m}^{3}$ ha $^{-1}$ & 1 & 0 & 3.34 & 23.86 & 168.93 & 0 & 3.38 & 29.96 & 250.17 & 0 & 2.07 & 18.58 & 57.43 \\
\hline $\mathrm{DW}>30$ & $\mathrm{~m}^{3}$ ha $^{-1}$ & 1 & 0 & 1 & 15.67 & 107.25 & 0 & 1 & 27.81 & 94.05 & 0 & 1 & 12.60 & 19.74 \\
\hline Recruitment & $\%$ & 1 & 0 & 25 & 75 & 100 & 0 & 25 & 75 & 100 & 0 & 25 & 75 & 100 \\
\hline Norway spruce & $\%$ & 5 & & & & & 0 & 30 & 35 & 100 & & & & \\
\hline Common beech & $\%$ & $4,4,5$ & 0 & 20 & 25 & 100 & 0 & 25 & 30 & 100 & 0 & 20 & 25 & 100 \\
\hline Silver fir & $\%$ & 5 & 0 & 30 & 35 & 100 & 0 & 70 & 75 & 100 & & & & \\
\hline Sessile oak & $\%$ & 5 & 0 & 75 & 80 & 100 & & & & & & & & \\
\hline Damaged & $\%$ & 2 & 0 & 21.43 & 50 & 100 & 0 & 18.75 & 55.88 & 100 & 0 & 21.62 & 59.09 & 87.50 \\
\hline Spatial indicators & & 1 & 0 & 25 & 75 & 100 & 0 & 25 & 75 & 100 & 0 & 25 & 75 & 100 \\
\hline Structural indicators & & 1 & 0 & 25 & 75 & 100 & 0 & 25 & 75 & 100 & 0 & 25 & 75 & 100 \\
\hline Viability indicators & & 1 & 0 & 25 & 75 & 100 & 0 & 25 & 75 & 100 & 0 & 25 & 75 & 100 \\
\hline
\end{tabular}


Table 5: Parameters of membership functions (MF) of type 3 with four parameters $a, b, c$ and $d$

\begin{tabular}{|l|c|c|c|c|c|c|c|c|c|}
\hline Criterion & FHT & MF Type & Unit & min & a & b & c & d & max \\
\hline Development phase & $9110,91 \mathrm{~K} 0,91 \mathrm{~L} 0$ & 3 & $\%$ & 0 & 30 & 45 & 55 & 70 & 100 \\
\hline Species composition - Hornbeam & $91 \mathrm{~L} 0$ & 3 & $\%$ & 0 & 10 & 15 & 45 & 50 & 100 \\
\hline Species composition - Sessile oak & $91 \mathrm{~L} 0$ & 3 & $\%$ & 0 & 20 & 25 & 85 & 90 & 100 \\
\hline Recruitment - Hornbeam & $91 \mathrm{~L} 0$ & 3 & $\%$ & 0 & 10 & 15 & 45 & 50 & 100 \\
\hline Recruitment - Sessile oak & $91 \mathrm{~L} 0$ & 3 & $\%$ & 0 & 20 & 25 & 85 & 90 & 100 \\
\hline
\end{tabular}

In the third stage, the same IF-THEN decision rules as defined for the DEX model were used. Furthermore, criteria were aggregated into the indicator groups by using the max-min composition of the membership functions (eq. (6)).

In the fourth stage we first defuzzified (eq. (7)) and normalized (eq. (8)) the results of all three groups of indicators. We then calculated the index of the conservation status of FHTs as the arithmetic mean of the final group-crisps. The input data (mean values), needed for the evaluation of FHTs by both models, are summarized in Table 6.

Table 6: Inputs for the DEX and fuzzy logic model

\begin{tabular}{|c|c|c|c|c|c|c|c|c|}
\hline \multirow{2}{*}{$\begin{array}{l}\text { Group of } \\
\text { indicators }\end{array}$} & \multirow{2}{*}{ Criterion } & \multicolumn{3}{|c|}{ DEX model } & \multicolumn{4}{|c|}{ Fuzzy model } \\
\hline & & FHT 9110 & FHT 91K0 & FHT 91L0 & unit & 9110 & $91 \mathrm{~K} 0$ & 91L0 \\
\hline \multirow{4}{*}{$\begin{array}{l}\text { Spatial } \\
\text { indicators }\end{array}$} & Core & least favorable & least favorable & least favorable & $\mathrm{m}$ & 135.54 & 174.11 & 127.68 \\
\hline & ForA & least favorable & least favorable & least favorable & ha $\mathrm{km}^{-2}$ & 70.32 & 82.88 & 67.80 \\
\hline & NofFHT & unfavorable & least favorable & least favorable & $\# \mathrm{~km}^{-2}$ & 1.98 & 1.64 & 1.88 \\
\hline & PSFHT & least favorable & least favorable & least favorable & ha $\mathrm{km}^{-2}$ & 48.25 & 69.12 & 47.32 \\
\hline \multirow{10}{*}{$\begin{array}{l}\text { Structural } \\
\text { indicators }\end{array}$} & $\begin{array}{l}\text { Species } \\
\text { composition }\end{array}$ & & & & $\%$ & & & \\
\hline & $\begin{array}{l}\begin{array}{l}\text { Norway } \\
\text { spruce }\end{array} \\
\end{array}$ & & favorable & & $\%$ & & 23.90 & \\
\hline & $\begin{array}{l}\text { Common } \\
\text { beech }\end{array}$ & favorable & favorable & favorable & $\%$ & 29.70 & 41.00 & 9.80 \\
\hline & Silver fir & favorable & favorable & & $\%$ & 1.50 & 6.30 & \\
\hline & Hornbeam & & & favorable & $\%$ & & & 20.60 \\
\hline & Sessile oak & favorable & & unfavorable & $\%$ & 8.50 & & 9.70 \\
\hline & $\begin{array}{l}\text { Development } \\
\text { phase }\end{array}$ & unfavorable & unfavorable & favorable & $\%$ & 20.00 & 31.00 & 46.00 \\
\hline & Vol & least favorable & least favorable & least favorable & $\mathrm{m}^{3} \mathrm{ha}^{-1}$ & 402.67 & 388.62 & 273.27 \\
\hline & Dwtotal & least favorable & least favorable & least favorable & $\mathrm{m}^{3} \mathrm{ha}^{-1}$ & 19.74 & 21.95 & 13.12 \\
\hline & $\mathrm{DW}>30$ & least favorable & least favorable & least favorable & $\mathrm{m}^{3} \mathrm{ha}^{-1}$ & 7.08 & 8.83 & 2.94 \\
\hline \multirow{7}{*}{$\begin{array}{l}\text { Viability } \\
\text { indicators }\end{array}$} & Recruitment & & & & $\%$ & & & \\
\hline & $\begin{array}{l}\text { Norway } \\
\text { spruce }\end{array}$ & & favorable & & $\%$ & & 17.00 & \\
\hline & $\begin{array}{l}\text { Common } \\
\text { beech }\end{array}$ & favorable & favorable & favorable & $\%$ & 43.00 & 45.00 & 19.00 \\
\hline & Silver fir & favorable & favorable & & $\%$ & 3.00 & 5.00 & \\
\hline & Hornbeam & & & favorable & $\%$ & & & 34.00 \\
\hline & Sessile oak & favorable & & unfavorable & $\%$ & 3.00 & & 8.00 \\
\hline & Damaged & least favorable & least favorable & least favorable & $\%$ & 36.47 & 38.39 & 40.48 \\
\hline
\end{tabular}




\section{Results}

The DEX model generated equal (least favorable) conservation statuses for all FHTs (Table 7). Apart from the Viability indicators, which ranged between favorable and least favorable, both remaining groups of indicators were evaluated as least favorable.

Table 7: Results of the DEX and fuzzy logic model

\begin{tabular}{|l|c|c|l|c|c|c|}
\hline \multirow{2}{*}{} & \multicolumn{3}{|c|}{ DEX model } & \multicolumn{3}{c|}{ Fuzzy model } \\
\cline { 2 - 7 } & 9110 & $91 \mathrm{~K} 0$ & $91 \mathrm{~L} 0$ & 9110 & $91 \mathrm{~K} 0$ & $91 \mathrm{~L} 0$ \\
\hline Spatial indicators & $\begin{array}{l}\text { least } \\
\text { favorable }\end{array}$ & $\begin{array}{l}\text { least } \\
\text { favorable }\end{array}$ & $\begin{array}{l}\text { least } \\
\text { favorable }\end{array}$ & 18.95 & 63.75 & 17.14 \\
\hline Structural indicators & $\begin{array}{l}\text { least } \\
\text { favorable }\end{array}$ & $\begin{array}{l}\text { least } \\
\text { favorable }\end{array}$ & $\begin{array}{l}\text { least } \\
\text { favorable }\end{array}$ & 42.01 & 49.49 & 50.00 \\
\hline Viability indicators & favorable & favorable & $\begin{array}{l}\text { least } \\
\text { favorable }\end{array}$ & 97.09 & 96.81 & 50.00 \\
\hline Conservation status & $\begin{array}{l}\text { least } \\
\text { favorable }\end{array}$ & $\begin{array}{l}\text { least } \\
\text { favorable }\end{array}$ & $\begin{array}{l}\text { least } \\
\text { favorable }\end{array}$ & $\mathbf{5 2 . 6 8}$ & $\mathbf{7 0 . 0 2}$ & $\mathbf{3 9 . 0 5}$ \\
\hline
\end{tabular}

Conversely, the fuzzy logic model aimed to provide more divergent results. While the 91K0 FHT and 91L0 FHT were classified at the descending continuum of conservation status values, the 9110 FHT was intermediate. The 9110 FHT gained a very good score for the Viability indicators, and good and bad scores for the Structural and Spatial indicators, respectively. The next 91K0 FHT gained a very good score for the Viability and good scores for the Spatial and Structural indicators. The last FHT, 91L0, gained good scores for the Structural and Viability indicators and a bad score for the Spatial indicators.

\section{Discussion}

The paper addressed two kinds of decision making models that potentially could be used for assessing diverse ecosystem/habitat traits. Compared to known habitat evaluations models (Hernando et al., 2010; Šmelko and Fabrika, 2007; Velázquez et al., 2010), both of the models evaluated significantly increased possibilities for more complex modeling by introducing the utility functions in the form of IF-THEN decision rules. Unlike simple matrix-based classifications and aggregations, giving a limited number of choices, the IF-THEN rules offered much more room for designing classification possibilities. As shown in 2.4 .2 and 2.4.3, their number was additionally enlarged by setting different weights to selected criteria (DEX model allows $6^{8}$ combinations; the fuzzy model enables unlimited choices due to continuous variables). Furthermore, a suite of IF-THEN decision rules also enabled us to aggregate logical and intuitive (similarity with human thinking) judgments and to assign unequal importance to the aggregated indicators (Nilashi et al., 2015). In this regard, new fuzzy logic models already combine different sorts of data and information such as quantitative and qualitative data, uncertainty, data imprecision as well as expert knowledge and experiences (Marchini et al., 2009).

The two models differed significantly. While the DEX model produced less tangible results, partly due to its original design (i.e. qualitative model) and partly to its greater robustness, the fuzzy model generated fully distinguishable outcomes that matched the existing assessments (Kutnar and Dakskobler, 2014; Kutnar et al., 2011) and national FHT evaluations (Eionet, 2018). Also adequate, compared to the DEX model, were the results on the aggregated Spatial, Structural and Viability indicators. Although the results of the DEX model were not as straightforward as of the fuzzy model, the model deserves further testing because of its modeling possibilities, with a focus on its robustness. The model should be tested with more contrasting FHTs which would allow setting clearer boundaries between the criteria and their critical values.

Despite being demanding in terms of workload, the fuzzy approach appeared to be useful for forest and nature conservation practitioners. If auxiliary information about FHTs exists, the model not only assists in determining possible drivers of the existing FHT conditions (e.g. viability group of indicators; insufficient regeneration -> ungulate herbivory or dieback; spatial indicators: fragmentation of FHT -> intensive forest clearing or unsuitable management), but it also helps set adequate conservation measures. Another important feature of both models is their suitability for conservation status assessments at different spatial levels, such as 
stand, ecosystem and landscape. The only condition that should be respected is that the spatial group of indicators must be omitted in the assessments at detailed spatial scales.

Finally, the presented models could have played a prominent role in making the reporting processes less biased. As confirmed by many scientific actions, reporting is an important tool for planning a sustainable future (MacDicken et al. 2015; Forest Europe, 2015; FAO, 2015). Unlike three decades ago, when forest information was mostly used for shaping national forest policies, many international agreements and commitments highlight the need for international collaboration and for comparable information from all parties. This idea and needs were clearly expressed by numerous scientific networks (i.e. COST E43) and contributions, which also addressed biodiversity conservation (Tomppo et al., 2009; Winter et al., 2008).

Natura 2000, in which forestlands comprise almost $50 \%$ of the area (European Commission, 2015), is perhaps the largest nature conservation network on Earth which is subject to regular reporting (Eionet, 2018). The reporting is currently mandatory for $28 \mathrm{EU}$ Member States. Since the launch of the Natura 2000 network, the harmonization of assessment methods and reporting formats has been a major challenge. Pursuant to this objective, the EU Commission and Member States (Evans and Arvela, 2011) developed reporting guidelines (Bensettiti et al., 2006; Ellmauer and Essl, 2005), largely based on the suggested indicators of nature conservation projects such as indirect and direct threats and stresses (Salafsky et al., 2008). Despite this effort, the reports produced by Member States remain of limited value due to bias and incomparability.

In addition to engaging different indicators, a great portion of inconsistency is associated with the different perception of the conservation status of FHTs. Similar to the perceptions of sustainable forest management, it greatly varies across Europe. To overcome different interpretations, an introduction of the minimum numbers of harmonized indicators for FHTs assessments within biogeographical regions would be meaningful. As assumed, the ten indicators, encased in three groups in this study, may not always be sufficient for a comprehensive FHT assessment. For this reason, the existing indicators and the groups of indicators/processes first should be tested for significance. Afterwards the list could be fulfilled with new indicators, which should be agreed, unambiguously defined and tested prior to put to operation. Such an approach is well known in panEuropean forest health inventorying (Eichhorn et al., 2010), where it has been conducted since the late 1980s. Once collected, the indicators could be used for evaluating the conservation status of FHTs directly (Kovač et al., 2016) or by modelling (Hernando et al., 2010; Šmelko and Fabrika, 2007; Velázquez et al., 2010). For large-sized FHTs, biodiversity indicators could be obtained through harmonized, integrated national forest inventories (Chirici et al., 2012; Kovač et al., 2014; Winter et al., 2008) and regional surveys. In the case of small-sized FHTs, special monitoring schemes are perhaps the most convenient.

The results presented in this paper revealed that the two models form a powerful system and could significantly contribute to the improvement of evaluations of FHT traits at the levels of nations and biogeographical regions. Yet, models also have drawbacks. They can easily become unmanageable and inconsistent (Štěpnička and De Baets, 2013) if the numbers of included criteria and inference rules are too large (Rodríguez et al., 2016).

\section{Acknowledgements}

This research paper was co-funded by the Research Programs P4 - 0107 and P4 - 0059, both financed by the Slovenian Research Agency. We are grateful to Dr. D. Hladnik, for having provided us with the indicator of ForA and to A.M. Kovač who helped us improve the language of the first version of the manuscript. Finally, we direct our sincere thanks to Prof. Dr. D.G. Hodges who kindly suggested improvements, improved the readability and proofread this manuscript and to two anonymous peer-reviewers for their critical comments and encouraging words that pushed us to improve an earlier version of the manuscript.

\section{References}

Adriaenssens, V., Baets, B.D., Goethals, P.L.M., Pauw, N.D., 2004. Fuzzy rule-based models for decision support in ecosystem management. Sci. Total Environ. 319 (2004), pp. 1-12. https://doi.org/10.1016/S0048$\underline{9697(03) 00433-9}$ 
Afrinaldi, F., Zhang, H.-C., 2014. A fuzzy logic based aggregation method for life cycle impact assessment. J. Clean Prod. 67, 159-172. http://dx.doi.org/10.1016/j.jclepro.2013.12.010

Ananda, J., Herath, G., 2009. A critical review of multi-criteria decision making methods with special reference to forest management and planning. Ecol. Econ. 68, 2535-2548.

doi:10.1016/j.ecolecon.2009.05.010

Bensettiti F., Puissauve R., Lepareur F., Touroult J., Maciejewski L., 2012. Evaluation de l'état de conservation des habitats et des espèces d'intérêt communautaire - Guide méthodologique - DHFF article 17, 2007-2012. Version 1 - Février 2012. Rapport SPN 2012-27, Service du patrimoine naturel, Muséum national d'histoire naturelle, Paris.

http://spn.mnhn.fr/spn rapports/archivage rapports/2012/SPN\%202012\%20-\%2027\%20-

\%20Guide_methodologique_EVAL_V1_fev-2012.pdf (Accessed 6.6. 2017)

Bohanec, M., 2013. DEXi: A Program for Multi-Attribute Decision Making, version 4.00.

Bohanec, M., Rajkovic, V., 1990. DEX: An expert system shell for decision support. Sistemica 1, 145-157. https://www.researchgate.net/profile/Marko_Bohanec/publication/284679050_DEX An Expert System Sh ell_for_Decision_Support/links/565840cf08ae4988a7b72b12/DEX-An-Expert-System-Shell-for-DecisionSupport.pdf (Accessed 6.6. 2017)

Bohanec, M., Rajkovič, V., Bratko, I., Zupan, B., Žnidaršič, M., 2012. DEX methodology: Thirty three years of qualitative multi-attribute modelling. Proceedings of the 15th International Conference Information Society IS 2012, Ljubljana, 8.-12.10. 2012, 31-34.

Cantarello, E., Newton, A.C., 2008. Identifying cost-effective indicators to assess the conservation status of forested habitats in Natura 2000 sites. For. Ecol. Manage. 256, 815-826. DOI:10.1016/j.foreco.2008.05.031

Carbajal-Hernández, J.J., Sánchez-Fernández, L.P., Carrasco-Ochoa, J.A., Martínez-Trinidad, J.F., 2012a. Assessment and prediction of air quality using fuzzy logic and autoregressive models. Atmos. Environ. 60, 37-50. http://dx.doi.org/10.1016/j.atmosenv.2012.06.004

Carbajal-Hernández, J.J., Sánchez-Fernández, L.P., Carrasco-Ochoa, J.A., Martínez-Trinidad, J.F., 2012b. Immediate water quality assessment in shrimp culture using fuzzy inference systems. Expert Syst. Appl. 39, 10571-10582. http://dx.doi.org/10.1016/j.eswa.2012.02.141

Che Osmi, S.F., Malek, M.A., Yusoff, M., Azman, N.H., Faizal, W.M., 2016. Development of river water quality management using fuzzy techniques: A review. Intl. J. River Basin Management 14, 243-254. http://dx.doi.org/10.1080/15715124.2015.1105232

Chirici, G., McRoberts, R.E., Winter, S., Bertini, R., Brändli, U.-B., Asensio, I.A., Bastrup-Birk, A., Rondeux, J., Barsoum, N., Marchetti, M., 2012. National forest inventory contributions to forest biodiversity monitoring. For. Sci. 58, 257-268. http://dx.doi.org/10.5849/forsci.12-003

Diaz-Balteiro, L., Romero, C., 2008. Making forestry decisions with multiple criteria: a review and an assessment. For. Ecol. Manage. 255, 3222-3241. doi:10.1016/j.foreco.2008.01.038

European Commission, 2007. Interpretation Manual of European Union Habitats - EUR27. European Commission, DG Environment.

http://ec.europa.eu/environment/nature/legislation/habitatsdirective/docs/2007_07_im.pdf (Accessed 6.6. 2017)

European Commission, 2015. Natura 2000 and Forests Part I-II. Technical report -2015 - 088.

http://ec.europa.eu/environment/nature/natura2000/management/docs/Final\%20Guide\%20N2000\%20\%20Fo rests\%20Part\%20I-II-Annexes.pdf (Accessed 6.6. 2017)

Eichhorn, J., Roskams, P., Ferretti, M., Mues, V., Szepesi, A., 2010. Visual Assessment of Crown Condition and Damaging Agents. Manual Part IV. UNECE ICP Forests Programme Co-ordinating Centre Hamburg, Hamburg.

Eionet (European Topic Centre on Biological Diversity), 2018. European Topic Centre on Biological Diversity. Reporting under Article 17 of the Habitats Directive (period 2007-2012). Outcomes from the Article17 reportsHabitat assessments at Member State level.

https://bd.eionet.europa.eu/article17/reports2012/habitat/report/?period=3\&group=Forests\&country=SI\&regi $\underline{\text { on }}$

Ellmauer, T., Essl, F., 2005. Entwicklung von Kriterien, Indikatoren und Schwellenwerten zur Beurteilung des Erhaltungszustandes der Natura 2000-Schutzgüter. Band 3: Lebensraumtypen des Anhangs I der FaunaFlora-Habitat-Richtlinie. Federal Environment Agency - Austria, Wien. 
http://www.researchgate.net/publication/267151082 Entwicklung_von_Kriterien_Indikatoren und Schwell enwerten zur Beurteilung des Erhaltungszustandes der Natura 2000-

Schutzgter Band 3 Lebensraumtypen des Anhangs I der Fauna-Flora-Habitat-Richtlinie (Accessed 6.6. 2017)

Evans, D., Arvela, M., 2011. Assessment and reporting under Article 17 of the Habitats Directive: Explanatory Notes \& Guidelines for the period 2007-2012. European Topic Centre on Biological Diversity. FAO, 2015. The Global Forest Resources Assessment. Rome: UN FAO.

Forest Europe, 2015. State of Europe’s Forests 2015. Madrid: Forest Europe, Madrid, Liaison Unit. Gharibi, H., Mahvi, A.H., Nabizadeh, R., Arabalibeik, H., Yunesian, M., Sowlat, M.H., 2012. A novel approach in water quality assessment based on fuzzy logic. J. Environ. Manage. 112, 87-95. http://dx.doi.org/10.1016/j.jenvman.2012.07.007

GIS/SFI, 2013. FFECS - Forest and forest ecosystem condition survey 1985-2013 - field data. Slovenian Forestry Institute, Ljubljana.

Hernando, A., Tejera, R., Velázquez, J., Núñez, M.V., 2010. Quantitatively defining the conservation status of Natura 2000 forest habitats and improving management options for enhancing biodiversity. Biodivers. Conserv. 19, 2221-2233. DOI 10.1007/s10531-010-9835-8

Herva, M., Roca, E., 2013. Review of combined approaches and multi-criteria analysis for corporate environmental evaluation. J. Clean Prod. 39, 355-371. https://doi.org/10.1016/j.jclepro.2012.07.058

Huang, I.B., Keisler, J., Linkov, I., 2011. Multi-criteria decision analysis in environmental sciences: Ten years of applications and trends. Sci. Total Environ. 409, 3578-3594. doi:10.1016/j.scitotenv.2011.06.022

Jamshidi, A., Yazdani-Chamzini, A., Yakhchali, S.H., Khaleghi, S., 2013. Developing a new fuzzy inference system for pipeline risk assessment. J. Loss Prev. Process Ind. 26, 197-208.

https://doi.org/10.1016/j.jlp.2012.10.010

Kampichler, C., Barthel, J., Wieland, R., 2000. Species density of foliage-dwelling spiders in field margins: a simple, fuzzy rule-based model. Ecol. Model. 129, 87-99. https://doi.org/10.1016/S0304-3800(00)00224-6

Kangas, J., Kangas, A., 2005. Multiple criteria decision support in forest management-the approach, methods applied, and experiences gained. For. Ecol. Manage. 207, 133-143.

https://doi.org/10.1016/j.foreco.2004.10.023

Kant Sharma, L., Kanga, S., Singh Nathawat, M., Sinha, S., Chandra Pandey, P., 2012. Fuzzy AHP for forest fire risk modeling. Disaster Prev. Manag. 21, 160-171. https://doi.org/10.1108/09653561211219964

Kaya, T., Kahraman, C., 2011. An integrated fuzzy AHP-ELECTRE methodology for environmental impact assessment. Expert Syst. Appl. 38, 8553-8562. https://doi.org/10.1016/j.eswa.2011.01.057

Kovac, P., Rodic, D., Pucovsky, V., Savkovic, B., Gostimirovic, M., 2012. Application of fuzzy logic and regression analysis for modeling surface roughness in face milliing. J. Intell. Manuf. 24, 755-762. DOI: 10.1007/s10845-012-0623-z

Kovač, M., Bauer, A., Ståhl, G., 2014. Merging National Forest and National Forest Health Inventories to Obtain an Integrated Forest Resource Inventory-Experiences from Bavaria, Slovenia and Sweden. PloS One 9, e100157. http://dx.doi.org/10.1371/journal.pone.0100157

Kovač, M., Kutnar, L., Hladnik, D., 2016. Assessing biodiversity and conservation status of the Natura 2000 forest habitat types: Tools for designated forestlands stewardship. For. Ecol. Manage. 359, 256-267.

http://dx.doi.org/10.1016/j.foreco.2015.10.011

Kutnar, L., Dakskobler, I., 2014. Evaluation of the Conservation Status of Forest Habitat Types (Natura 2000) and Their Forest Management. Professional Journal of Forestry 72, 419-439.

Kutnar, L., Matijašič, D., Pisek, R., 2011. Conservation status and potential threats to Natura 2000 forest habitats in Slovenia. Sumar. List 135, 215-230. http://hrcak.srce.hr/71628

Lermontov, A., Yokoyama, L., Lermontov, M., Machado, M.A.S., 2009. River quality analysis using fuzzy water quality index: Ribeira do Iguape river watershed, Brazil. Ecol. Indic. 9, 1188-1197. https://doi.org/10.1016/j.ecolind.2009.02.006

MacDicken, K. G., Sola, P., Hall, J. E., Sabogal, C., Tadoum, M., de Wasseige, C. 2015. Global progress toward sustainable forest management. Forest Ecology and Management, 352, 47-56. doi.:

http://dx.doi.org/10.1016/j.foreco.2015.02.005 
Mahapatra, S.S., Nanda, S.K., Panigrahy, B.K., 2011. A Cascaded Fuzzy Inference System for Indian river water quality prediction. Adv. Eng. Softw. 42, 787-796. https://doi.org/10.1016/j.advengsoft.2011.05.018 Mamdani, E.H., Assilian, S., 1975. An experiment in linguistic synthesis with a fuzzy logic controller. Int. J. Man Mach. Stud. 7, 1-13. https://doi.org/10.1016/S0020-7373(75)80002-2

Marchini, A., Facchinetti, T., Mistri, M., 2009. F-IND: A framework to design fuzzy indices of environmental conditions. Ecol. Indic. 9, 485-496. https://doi.org/10.1016/j.ecolind.2008.07.004

Mehtälä, J., Vuorisalo, T., 2007. Conservation policy and the EU Habitats Directive: favourable conservation status as a measure of conservation success. Eur. Environ. 17, 363-375. DOI: 10.1002/eet.458

Mocq, J., St-Hilaire, A., Cunjak, R.A., 2013. Assessment of Atlantic salmon (Salmo salar) habitat quality and its uncertainty using a multiple-expert fuzzy model applied to the Romaine River (Canada). Ecol. Model. 265, 14-25. https://doi.org/10.1016/j.ecolmodel.2013.05.020

Monjezi, M., Rezaei, M., 2011. Developing a new fuzzy model to predict burden from rock geomechanical properties. Expert Syst. Appl. 38, 9266-9273. https://doi.org/10.1016/j.eswa.2011.01.029

Mosadeghi, R., Warnken, J., Tomlinson, R., Mirfenderesk, H., 2015. Comparison of Fuzzy-AHP and AHP in a spatial multi-criteria decision making model for urban land-use planning. Comput. Environ. Urban Syst. 49, 54-65. https://doi.org/10.1016/j.compenvurbsys.2014.10.001

Müller-Kroehling, S., Fischer, M., Gulder, H.-J., Walentowski, H., Kölling, C., 2004. Arbeitsanweisung zur Fertigung von Managementplänen für Waldflächen in NATURA 2000-Gebieten. Bayerische Landesanst. für Wald und Forstwirtschaft.

https://www.lwf.bayern.de/mam/cms04/biodiversitaet/dateien/arbeitsanweisung.pdf

Nilashi, M., Zakaria, R., Ibrahim, O., Majid, M.Z.A., Mohamad Zin, R., Chugtai, M.W., Zainal Abidin, N.I., Sahamir, S.R., Aminu Yakubu, D., 2015. A knowledge-based expert system for assessing the performance level of green buildings. Knowl-Based Syst. 86, 194-209. https://doi.org/10.1016/j.knosys.2015.06.009

Ocampo-Duque, W., Ferré-Huguet, N., Domingo, J.L., Schuhmacher, M., 2006. Assessing water quality in rivers with fuzzy inference systems: A case study. Environ. Int. 32, 733-742.

https://doi.org/10.1016/j.envint.2006.03.009

Ochoa-Gaona, S., Kampichler, C., de Jong, B.H.J., Hernández, S., Geissen, V., Huerta, E., 2010. A multicriterion index for the evaluation of local tropical forest conditions in Mexico. For.Ecol. Manage. 260, 618627. https://doi.org/10.1016/j.foreco.2010.05.018

OJEC, 1992. Council Directive 92/43/EEC of 21 May 1992 on the conservation of natural habitats and of wild fauna and flora. Off. J. Eur. Commun., L, 206. http://eur-lex.europa.eu/legalcontent/EN/TXT/?uri=CELEX:31992L0043 (Accessed 6.6. 2017)

Peche, R., Rodríguez, E., 2012. Development of environmental quality indexes based on fuzzy logic. A case study. Ecol. Indic. 23, 555-565. https://doi.org/10.1016/j.ecolind.2012.04.029

Rodríguez, A., Ortega, F., Concepción, R., 2016. A method for the evaluation of risk in IT projects. Expert Syst. Appl. 45, 273-285. https://doi.org/10.1016/j.eswa.2015.09.056

Ross, T.J., 2004. Fuzzy logic with engineering applications. Wiley, New York.

Rozman, Č., Potočnik, M., Pažek, K., Borec, A., Majkovič, D., Bohanec, M., 2009. A multi-criteria assessment of tourist farm service quality. Tourism Manage. 30, 629-637.

https://doi.org/10.1016/j.tourman.2008.11.008

Salafsky, N., Salzer, D., Stattersfield, A.J., HILTON-TAYLOR, C., Neugarten, R., Butchart, S.H., Collen, B., Cox, N., Master, L.L., O'CONNOR, S., 2008. A standard lexicon for biodiversity conservation: unified classifications of threats and actions. Conserv. Biol. 22, 897-911. DOI: 10.1111/j.1523-1739.2008.00937.x

Scolozzi, R., Geneletti, D., 2012. A multi-scale qualitative approach to assess the impact of urbanization on natural habitats and their connectivity. Environ. Impact Asses. 36, 9-22.

https://doi.org/10.1016/j.eiar.2012.03.001

Silvert, W., 2000. Fuzzy indices of environmental conditions. Ecol. Model. 130, 111-119.

https://doi.org/10.1016/S0304-3800(00)00204-0

StatSoft-Inc, 2011. STATISTICA data analysis software system, v. 10.0.

Stubelj Ars, M., Bohanec, M., 2010. Towards the ecotourism: A decision support model for the assessment of sustainability of mountain huts in the Alps. J. Environ. Manage. 91, 2554-2564.

https://doi.org/10.1016/j.jenvman.2010.07.006 
Šmelko, Š., Fabrika, M., 2007. Evaluation of qualitative attributes of forest ecosystems by means of numerical quantifiers. J. For. Sci. 53, 529. http://81.0.228.28/publicFiles/00531.pdf (Accesssed 6.6. 2017) Štěpnička, M., De Baets, B., 2013. Implication-based models of monotone fuzzy rule bases. Fuzzy Set. Syst. 232, 134-155. https://doi.org/10.1016/j.fss.2013.07.019

Tomppo, E., Gschwantner, T., Lawrence, M., McRoberts, R.E., 2009. National Forest Inventories. Pathways for Common Reporting. Springer, Heidelberg, Dordrect, London, New York.

Velázquez, J., Tejera, R., Hernando, A., Núñez, M.V., 2010. Environmental diagnosis: Integrating biodiversity conservation in management of Natura 2000 forest spaces. J. Nat. Conserv. 18, 309-317. https://doi.org/10.1016/j.jnc.2010.01.004

Vesely, S., Klöckner, C.A., Dohnal, M., 2016. Predicting recycling behaviour: Comparison of a linear regression model and a fuzzy logic model. Waste Manage. 49, 530-536.

https://doi.org/10.1016/j.wasman.2015.12.025

Winter, S., Chirici, G., McRoberts, R.E., Hauk, E., 2008. Possibilities for harmonizing national forest inventory data for use in forest biodiversity assessments. Forestry 81, 33-44.

Yan, H., Zou, Z., Wang, H., 2010. Adaptive neuro fuzzy inference system for classification of water quality status. J. Environ. Sci. 22, 1891-1896. https://doi.org/10.1016/S1001-0742(09)60335-1

Zadeh, L.A., 1965. Fuzzy sets. Inform. Control 8, 338-353. https://doi.org/10.1016/S0019-9958(65)90241-X

Zopounidis, C., Doumpos, M., 2002. Multicriteria classification and sorting methods: A literature review.

Eur. J. Oper. Res. 138, 229-246. https://doi.org/10.1016/S0377-2217(01)00243-0 